\title{
Wither the Impact of Celebrity Endorsement
}

\author{
Karen S. Freeman, Malaysia \\ Cathy C. Chen, Malaysia
}

\begin{abstract}
The advertising and entertainment industry have changed radically over the years. Celebrities today are much more influential and enjoy a much higher public profile than in the past. This includes not just actors or singers, but sports personalities and reality show stars. This ongoing public fascination with celebrities offers advertisers a wide range of creative ideas to attract audiences and has established celebrity endorsement as a popular promotional tool. This research seeks to evaluate the impact of celebrity endorsement on young adults in Malaysia. It examines the relationship between the key attributes of celebrity endorsers, based on the TEARS model, and consumers' purchase intentions. These attributes are: trustworthiness, expertise, physical attractiveness, respect and similarity. The study adopts a quantitative approach, with a structured questionnaire as the main tool. Based on a survey of 318 young adults, the findings show that four of the five TEARS attributes significantly influence consumers' purchase intentions; only one, expertise, does not.
\end{abstract}




\section{Introduction}

Companies have long used characters of note to help promote their products. Given the rise in product diversity today this has led to an increase in the amounts spent on promotional initiatives by many organizations. One way to achieve this is through celebrity endorsement, which has become one of the most popular advertising strategies for promoting various types of products, services or brands (Biswas, Hussain \& O’Donnell, 2009).

Companies sign deals with celebrities in the hope and expectation that this will help them stand out from the clutter and give them a unique and relevant position in the minds of consumers (Temperley \& Tangen, 2006). These celebrities then act as spokespersons to advertise and promote the company's products, services or ideas. Celebrity endorsement has become very popular in modern marketing (McCracken, 1989; Choi \& Rifon, 2007). For example, the famous footballer David Beckham endorses the sports brand Adidas; Korean actress Soon Hye Kyo endorses the cosmetic brand Laneige; American singer Beyoncé endorses Pepsi and the fashion brand H\&M; American actress Nicole Kidman endorses Omega watches; and many more.

In fact, companies in Malaysia spend millions on celebrity endorsements (Tan, 2011). For example, Chef Wan endorses Yeo's products; badminton player Lee Chong Wei is a brand marketer for Yonex badminton shoes, Samsung Galaxy S3 mobile phones, Cafe 99 and Kaspersky; and Rozita Che Wan endorses Safi's products.

With the world of modern marketing communication becoming increasingly inundated with advertisements, this has made it harder for any one advertisement to get noticed. It is an uphill task for advertisers to differentiate their campaigns and attract viewers. According to Kambitsis et al. (2002), this has led to not only the increased use of celebrities in advertising strategies, but also their use in increasingly sophisticated and complicated ways. Advertisers are willing to pay huge salaries to celebrities who are liked and respected by target audiences and who will favorably influence consumers' attitudes and behavior (Shimp \& Andrews, 2013). Forbes Magazine (2014) lists the top 100 celebrities by measuring how much they earn, as well as their web hits, press clips and TV/radio appearances. Today, almost all of these top celebrities have exclusive endorsement contracts. Petty, Cacioppo \& Schumann (1983) claimed that unlike anonymous endorsers, celebrities add value to the image transfer 
process, sustaining brand communication and thereby achieving a higher level of attention and recall. Research has shown that the use of celebrities in advertising can have a positive influence on the credibility of and preferences for advertising, and ultimately on purchase intentions (Farhat \& Khan, 2011). Conversely, Tom et al. (1992) concluded that non-celebrity endorsers were more effective in creating a link to the product as their characters could be developed and molded to fit the brands and target audiences. Mehta (1994) too found no significant differences between celebrity and non-celebrity endorsements in regard to attitudes towards the advertisement, attitudes towards the brand, and intentions to purchase the endorsed brands. In spite of any arguments against celebrity endorsement, this type of advertising remains one of the most popular advertising strategies. Indeed, it is a "ubiquitous feature of modern day marketing'” (Biswas, Hussain \& O’Donnell, 2009).

Adding to this complexity is information derived from the Elaboration Likelihood Model (ELM) developed by Petty, Cacioppo \& Schumann (1983). ELM states that a person's existing attitudes can be changed, i.e. they can be persuaded by a message or advertisement, but, there are two possible routes that can be taken to that change. Under conditions of high involvement, consumers' attitudes change through the central route to persuasion. This central route consists of "thoughtful consideration of the arguments (ideas, content) in the message" (Benoit et al., 2001). In this case, consumers are more likely to be influenced by a particular product's true qualities rather than the impact of any celebrity endorsement. Under conditions of low involvement, consumers' attitudes change through the peripheral route to persuasion. Messages sent via the peripheral route are not processed cognitively. In such cases, consumers are far more likely to be influenced by celebrity endorsement.

A substantial amount of such research has been conducted in the U.S., UK, Canada, India, Hong Kong and Taiwan. However, there has been only limited research in Malaysia specifically investigating the relationship of the specific attributes of endorsers and their impact on consumers' purchasing intentions.

\section{Literature Review}

\section{Celebrity Endorsement}

Roll (2006) described celebrities as people who are widely known to the public for their accomplishments in their respective fields, be it the movies, sport, music or politics. In a 
market with a very high proliferation of local, regional and international brands, celebrity endorsement is thought to provide a distinct differentiation.

In his study, Mustafa (2005) states that, although it would be possible to employ anonymous models for a fraction of the price, celebrities hold special qualities. Anonymous models offer demographic information such as gender, age and status, but these meanings are blunt and imprecise. Celebrities offer a variety of lifestyle meanings and personalities that anonymous models cannot provide. Moreover, celebrities are more powerful media than nameless models. Unlike anonymous endorsers, celebrities add value to the image transfer process, sustaining brand communication and achieving a higher level of attention and recall (Song, Chaipoopiratana \& Combs, 2008).

Nevertheless, as with any dynamic advertising/marketing communication efforts, there are some elements of risk. Endorsement relationships can turn sour and perceptions can change if celebrities face negative publicity (White, Goddard \& Wilbur, 2009). For example, the Mike Tyson jail sentence, the O.J. Simpson murder case, the Tiger Woods sex scandal, and actress Zhang Ziyi's charity fraud. When the negative image of a celebrity is exposed, the organization's brand image is in turn tarnished, causing a fall in consumer trust and confidence (Nelson, 2010). Additionally, celebrity endorsements are susceptible to other risks, such as a drop in the celebrities' popularity or a sudden change in their personality and image (Johansson \& Sparredal, 2002 and Ericsson \& Hakansson, 2005). In sum, celebrity endorsement efforts, can work against an organization.

\section{The Elaboration Likelihood Model (ELM)}

According to Petty, Cacioppo and Schumann (1983), understanding attitudes is a key area in consumer behavior research. Researchers and advertisers have devoted a great deal of time and effort to determine how to change buyers' attitudes so as to sell their brands. As a result, ELM has become an influential tool in studying attitudes and persuasion. Under conditions of high involvement, the attitude change is processed through the central route. If people are motivated and are able to think carefully about a message, then they are likely to follow the central route to persuasion. In the central route, individuals carefully consider the elements of the message in order to determine whether its proposal makes sense and will benefit them. The central route is used to process information that the viewer finds to be vital to the true 
qualities of a particular attitudinal position (Wagner \& Petty, 2011). In sum, under conditions of high involvement, arguments and not celebrities influenced attitudes.

Attitude and therefore even behavior change can occur even if there is little or no consideration of the arguments contained in a message. In ELM, such processes are categorized as the peripheral route to persuasion. This involves mechanisms where message recipients use simple cues or mental shortcuts as a means of processing the information in a message (Petty, Cacioppo, \& Schumann, 1983). For example, a cue might involve an emotional state (e.g., happiness) that becomes associated with the message's advocated position in a positive way; or, a recipient simply agreeing with a message because it is delivered by a perceived expert (activating a mental shortcut which says that "experts are generally correct"). In such cases, “consumers' attitudes are based on a more tangential or superficial analysis of the message, not on an effortful analysis of its true merits" (Hoyer \& MacInnis, 2007).

\section{Race and Gender}

There are three major ethnic groups in Malaysia - Malays, Chinese and Indians. Rashid, Nallamuthuet \& Sidin (2002) found that there is a significant difference between Malay, Chinese and Indian consumers attitudes' towards advertising by celebrities. The Malays and Chinese were more familiar with certain celebrities. In another study between two countries, Wang (2006) concluded that the more attractive and the higher the expertise of a celebrity athlete endorser, the more likely that consumers in China will purchase that product; whereas, in Canada it is the expertise of the celebrity endorser which determines whether consumers are likely to purchase the product.

In regard to gender, Elliott (2006) found that males are more likely to make emotional buying decisions based on partially digested information. They do not require a lot of information or details when making a purchase decision. Besides, males view shopping as a purchase-driven activity, i.e. they go shopping only when there is a need. Brown (2011) claims that males are easily hooked by humor, by distinctive creative styles, and by sexual imagery in advertisements. Further, they prefer messages which are to the point and not complicated, and the research also found that colors and pictures in advertisements can better grab a male's attention. In addition, males like women featured in advertisements more than females do. All 
this suggesting that a male's attitude towards advertisements tends to change through the peripheral route. Females, on the other hand, tend to be more sensitive to and mindful of the details of the information contained in advertisements, and so their attitudes more often change through the central route. Females therefore prefer more detailed advertisements with a clear message. They also favor objective over subjective claims, although they are most susceptible to a combination of emotional and rational factors (Elliott, 2006).

\section{The TEARS Model}

Many studies of celebrity endorsement look at the 'endorser effect' construct based on endorser characteristics. These endorser characteristics influence the persuasiveness of the communication conveyed to the target audience. Shimp (2003) stated that the endorser effect has two general attributes, credibility and attractiveness, which contributes to an endorser's effectiveness, and that each consists of further distinct sub-attributes. The acronym TEARS is used to represent five discrete attributes: trustworthiness and expertise are two dimensions of credibility; whereas physical attractiveness, respect and similarity (to the target audience) are components of the general concept of attractiveness.

\section{Credibility}

Credibility refers to the extent to which the source is recognized as possessing significant knowledge or experience to offer an unbiased judgment (Carroll, 2008). If information comes from a credible source, consumers' attitudes, values, opinions and behaviors can be influenced through 'internalization' (Ohanian, 1991; Daneshvary \& Schwer, 2000). Internalization happens when consumers allow a source to influence their personal attitudes and values. As stated by Daneshvary \& Schwer (2000), an individual accepts the influence of the source not only because it offers a solution to a problem but also because of the source's own credibility. Therefore, the endorsement of a product by a credible source may affect consumers' behavioral intentions. Pornpitakpan (2003) and Belch \& Belch (2003) stated that, when celebrities are credible, this can positively affect the acceptance of the message and the degree of persuasion. In addition, endorsement by a credible source is effective when used on consumers who initially have negative perceptions towards the product (Daneshvary \& Schwer, 2000). The credible source can neutralize these perceptions, resulting in greater message acceptance (Bryne, Whitehead \& Breen, 2003). 
Generally, two important sub-attributes underline the concept of endorser credibility: trustworthiness and expertise (McCracken, 1989; Liu et al., 2007; Chen \& Huddleston, 2009). In fact, according to Toncar et al. (2007), trustworthiness and expertise contribute independently to endorser effectiveness.

\section{Trustworthiness}

Trustworthiness is the first dimension of endorser credibility (McCracken 1989); and the T term in the TEARS model (Shimp, 2003). Erdogan (1999) defined trustworthiness as a consumer's perception of the honesty, integrity and believability of an endorser. Further, Shimp (2003) argues that a celebrity endorser is trusted by the target audience due to the life he or she lives professionally and personally, as revealed to the general public through the mass media.

As O’Mahony \& Meenaghan (1997) showed, source trustworthiness is a basic attribute underlying source credibility that fundamentally affects attitudinal change in consumers. Without trustworthiness, the other attributes possessed by the endorser are unlikely to be effective in changing consumers' attitudes. This is consistent with Atkin and Block (1983), who postulated that celebrities are perceived to be more trustworthy than non-celebrities, since consumers are more easily influenced by someone they perceive to have higher standards. Priester \& Petty (2003) noted that if a celebrity endorser is perceived to be highly trustworthy, a consumer might not scrutinize the advertising message as much and may unthinkingly accept the conclusion as valid. Part of this effectiveness is also derived from explanations of the ELM.

\section{Expertise}

Expertise is the second dimension of endorser credibility (McCracken, 1989); and the E component of the TEARS model (Shimp, 2003). According to Erdogan (1999), expertise in endorser credibility refers to knowledge, experience, and skills with regard to the advertised brand. Endorsers are considered to be 'experts' when they endorse products related to areas that have made them popular (Biswas et al., 2006). For instance, athletes are considered to be experts when it comes to endorsing sports-related products. Models are similarly perceived as possessing expertise with regard to beauty-enhancing products and fashion items. Shimp (2003) stated that an endorser who is perceived as an expert on a given subject will be more 
persuasive in changing audience opinions pertaining to his or her area of expertise than an endorser who is not perceived as possessing the same characteristic.

Silvera \& Austad (2004) found that the expertise of an endorser correlates with the validity of the claims concerning the product, and is thus an important factor in increasing the persuasiveness of marketing messages. In addition, the expertise of a celebrity provides consumers with more concrete information on the product offering, which can then lead to a favorable attitude towards the brand (Magnini et al., 2008).

\section{Attractiveness}

The second general attribute that contributes to endorser effectiveness is attractiveness (McCracken 1989; Shimp, 2003). When consumers find something in an endorser that they consider attractive, persuasion occurs through identification. Identification occurs when "individuals conform to the attitude or behavior advocated by another person because these individuals derive satisfaction from the belief that they are like that person'" (Friedman \& Friedman, 1979). Identification is related to likeability and attractiveness, and is arguably the process that best explains persuasion by a celebrity endorser. The TEARS model identifies three sub-components of the general concept of attractiveness: physical attractiveness, respect, and similarity (Shimp, 2003). Perceived attractiveness is achieved via any one of these attributes, and does not require that a celebrity encompass all of these simultaneously.

\section{Physical Attractiveness}

Physical Attractiveness is the A component in the TEARS model and is a key consideration in many endorsement relationships (Ohanian, 1990). Physical attractiveness includes any number of virtuous characteristics that consumers may perceive in an endorser: intellectual skills, personality properties, lifestyle characteristics, athletic prowess, and so on (Shimp, 2003).

Research has supported the intuitive expectation that physically attractive endorsers generally produce more favorable evaluations of advertisements and the brands than do less attractive communicators (Kahle \& Homer, 1985). However, Bryne, Whitehead \& Breen (2003) found that their influence on repeat purchase intentions is ambiguous, as attractiveness alone may not be sufficient. There is also a risk that celebrities may overshadow brands. Nevertheless, 
Belch \& Belch (2003) contend that companies spend huge amounts of money to have celebrities endorse their products because celebrities have what they call 'stopping power' they can make advertising messages stand out in a cluttered media environment. Furthermore, Till \& Busler (2000) found that there is a "physical attractiveness effect" on individuals' attitudes to brands and purchase intentions.

\section{Respect}

Respect, the $\mathrm{R}$ in the TEARS model, is the second component of the overall attractiveness attribute. Respect refers to the quality of being admired or even esteemed due to the endorser's accomplishments. Celebrities are respected for their acting ability, athletic prowess, appealing personalities, their stand on important societal issues, and other qualities. Celebrities who are respected are also generally liked, and likeability arises from a fondness for the endorsers because of their behavior, physical appearance or other traits (Bryne, Whitehead \& Breen, 2003).

When respected/liked celebrities enter into endorsement relationships with various brands, the respect/liking of the celebrities may extend to the brands they are linked to, thus enhancing the brand's equity via positive effects on consumers' attitudes toward the brand (Shimp, 2003). Charbonneau and Garland (2005) found that using a credible and respected celebrity or athlete as the 'voice' (message carrier) is more effective than using an ordinary model. Celebrities can deliver meanings to advertisements with extra subtlety, depth and power. While anonymous models can represent certain positive demographic information (gender, age and status), celebrities can offer these elements with greater precision (McCracken, 1989). Celebrities are usually associated with high status due to their recognition, and the extra qualities and power that they gain via repeated media exposure (La Eerie \& Sejung, 2005).

\section{Similarity}

Similarity, the third attractiveness component and the $\mathrm{S}$ term in the TEARS model, represents the degree to which an endorser matches an audience in terms of characteristics pertinent to the endorsement relationship - age, gender, ethnicity, etc. (Shimp, 2003). In addition, Erdogan (1999) defined similarity as a supposed resemblance between the source and the receiver of the message. Desphande \& Stayman (1994) found that endorsers' ethnic status 
affects perceptions of trustworthiness and as a result brand attitudes. The researchers hypothesized that this occurs because people trust individuals who are similar to them.

These findings support the claim made by Cialdini (2007) that we like people who are similar to us and that "this fact seems to hold true whether the similarity is in the areas of opinions, personality traits, background or lifestyle". Meanwhile, Shimp (2003) claimed that similarity between the endorser and audience is especially important when there is a wide range of products or services on offer and where audience members are heterogeneous. In such cases, a spokesperson perceived to be similar to the audience is likely to have the greatest effect in influencing attitudes and choices.

\section{Purchase Intentions}

Purchase intentions are the probability of consumers buying a product, or a consumer's conscious plans to make an effort to purchase a brand (Spears \& Singh, 2004). According to Kwek (2010), they are also a component of consumer cognitive behavior, i.e., how and why consumers intend to buy a specific product, service or brand. The higher the purchase intentions are, the higher a consumer's willingness is to buy a given product.

Furthermore, Sheu (2010) found that consumers' purchase intentions are easily affected by many external factors during their decision-making processes. For instance, during the purchase process itself, their purchase intentions can be affected by the product attributes, price and the performance of the endorser - as perceived by the consumers. Just as consumers' purchase intentions are easily triggered by promotion strategies, so their attitudes towards the promoted products, services or brands are also easily affected by the popularity and image of the celebrity doing the promoting. Moreover, when consumers treat celebrities as their reference group, they very often want to imitate them in an effort to feel successful too (Forbes, 2011). Research has shown that the use of celebrities in advertisements can have a positive influence on credibility, message recall, memory and likeability with regard to advertisements, and ultimately on purchase intentions (Pornpitakpan, 2003; Pringle \& Binet, 2005; Roy, 2006). In sum, consumers' purchase intentions can be positively influenced by celebrities they admire. Based on prevailing literature, this study draws on five hypotheses where the trustworthiness, expertise, physical attractiveness, respect and similarity all have a significant and positive relationship with consumers' purchasing intentions. 


\section{Methodology}

As part of the questionnaire, four categories of color print advertisements were selected as the stimulus material, which included advertisements for beverages, sports goods, perfumes, and mobile phones. Before giving out the questionnaires, the stimulus advertisements were shown to the respondents.

The first section of the questionnaire adopts a five-point Likert Scale to determine respondents' feelings towards the five attributes of celebrity endorsers (trustworthiness, expertise, physical attractiveness, similarity, respect). The second section consists of questions about consumers' purchase intentions based on the impact of celebrity endorsement while the third section is designed to gather demographic data. The target population is Malaysian young adults aged between 18-25 years and comprising the three major races in Malaysia, namely, Malays, Chinese and Indians.

The calculated sample size of this study is 385 respondents based on the target population of 5,000,000 young adults in Malaysia (Department of Statistics Malaysia, 2013). A pilot test comprising 30 respondents was conducted to ensure that the questionnaire was suitable for Malaysians. A second pilot test was run to test its reliability.

\section{Results and Discussion}

An Independent T-test was run for the purchase intentions by gender. The F value of 0.140 $(\operatorname{sig} .=0.708>0.05)$ indicates that there is no significant difference in the purchase intentions of males and females. Meanwhile, a One-Way ANOVA Test for differences in purchase intentions by race shows that the results is statistically significant (sig. $=0.11<0.05$ ), so equal variance is not assumed. The Robust Tests of Equality of Means shows that both the Welch and Brown-Forsythe tests are statistically significant (sig.=0.000). These results point to significant differences between groups. Since equal variance was not assumed, Dunnett's T3 test was conducted to determine which groups were different. Also, with the ANOVA results, the $\mathrm{F}$ value of 35.981 (sig.= 0.000) indicates that race has a significant influence on purchase intentions at the $1 \%$ level. Each group is significantly different from the other groups at the $5 \%$ level. In addition, the purchase intentions of the Chinese $($ mean $=15.65)$ are significantly higher than those of the Indians (mean $=13.66)$ or Malays $($ mean $=12.27)$. 
Table 1 shows the fairly high Cronbach's alpha values for all variables ranging from 0.868 to 0.939. The reliability of all the independent variables was also measured in the same way. The resulting Cronbach's Alpha value for all items produced a Cronbach's alpha value of 0.924 , denoting reliability.

Table 1: Summary of Reliability Test

\begin{tabular}{llc}
\hline Cronbach's Alpha Reliability Analysis & \\
\hline Variables & Measurement & Cronbach's \\
& Items & Alpha \\
\hline Trustworthiness & T1, T2, T3, T4, & 0.939 \\
& T5, T6 & \\
\hline Expertise & E1, E2, E3, E4, & 0.925 \\
& E5, E6 & \\
\hline Physical & A1, A2, A3, A4, & 0.868 \\
Attractiveness & A5, A6 & \\
\hline Respect & R1, R2, R3, R4, & 0.934 \\
& R5, R6 & \\
\hline Similarity & S1, S2, S3, S4, S5, & 0.925 \\
& S6 \\
\hline Purchase & P1, P2, P3, P4 & 0.923 \\
Intentions & \\
\hline
\end{tabular}

The research model in this study consists of five reflective constructs: purchase intentions (dependent variable), trustworthiness, expertise, physical attractiveness, respect and similarity. Table II shows the outer model evaluation for the reflective constructs.

Table II: Results of Outer Model Evaluation

\begin{tabular}{|c|c|c|c|c|}
\hline Latent & Indic & Loadi & Composite & AVE \\
Variables & ator & ng & Reliability & \\
\hline
\end{tabular}




\begin{tabular}{|c|c|c|c|c|}
\hline $\begin{array}{c}\text { Trustworthi } \\
\text { ness }\end{array}$ & $\begin{array}{l}\mathrm{T} 1 \\
\mathrm{~T} 2 \\
\mathrm{~T} 3 \\
\mathrm{~T} 4 \\
\mathrm{~T} 5 \\
\mathrm{~T} 6\end{array}$ & $\begin{array}{l}0.823 \\
0.858 \\
0.861 \\
0.859 \\
0.824 \\
0.798\end{array}$ & 0.934 & 0.701 \\
\hline Expertise & $\begin{array}{l}\text { E1 } \\
\text { E2 } \\
\text { E3 } \\
\text { E4 } \\
\text { E5 } \\
\text { E6 }\end{array}$ & $\begin{array}{l}0.878 \\
0.922 \\
0.924 \\
0.920 \\
0.936 \\
0.887\end{array}$ & 0.967 & 0.831 \\
\hline $\begin{array}{c}\text { Physical } \\
\text { Attractivene } \\
\text { ss }\end{array}$ & $\begin{array}{l}\text { A1 } \\
\text { A2 } \\
\text { A3 } \\
\text { A5 } \\
\text { A6 }\end{array}$ & $\begin{array}{l}0.858 \\
0.928 \\
0.757 \\
0.761 \\
0.922\end{array}$ & 0.927 & 0.720 \\
\hline Respect & $\begin{array}{l}\text { R1 } \\
\text { R2 } \\
\text { R3 } \\
\text { R4 } \\
\text { R5 } \\
\text { R6 }\end{array}$ & $\begin{array}{l}0.722 \\
0.751 \\
0.918 \\
0.901 \\
0.925 \\
0.785\end{array}$ & 0.933 & 0.702 \\
\hline Similarity & $\begin{array}{l}\text { S1 } \\
\text { S2 } \\
\text { S3 } \\
\text { S4 } \\
\text { S5 } \\
\text { S6 }\end{array}$ & $\begin{array}{l}0.866 \\
0.833 \\
0.877 \\
0.850 \\
0.891 \\
0.867\end{array}$ & 0.947 & 0.747 \\
\hline $\begin{array}{l}\text { Purchase } \\
\text { Intentions }\end{array}$ & $\begin{array}{l}\mathrm{P} 1 \\
\mathrm{P} 2 \\
\mathrm{P} 3\end{array}$ & $\begin{array}{l}0.801 \\
0.758 \\
0.936\end{array}$ & 0.919 & 0.742 \\
\hline
\end{tabular}




\begin{tabular}{|l|l|l|l|l|}
\hline & P4 & 0.935 & & \\
\hline
\end{tabular}

Table III: Correlations of Latent Variables

\begin{tabular}{|l|l|l|l|l|l|l|}
\hline & $\begin{array}{l}\text { Exper } \\
\text { tise }\end{array}$ & $\begin{array}{l}\text { Physical } \\
\text { Attractiven } \\
\text { ess }\end{array}$ & $\begin{array}{l}\text { Purchase } \\
\text { Intention } \\
\text { s }\end{array}$ & $\begin{array}{l}\text { Resp } \\
\text { ect }\end{array}$ & $\begin{array}{l}\text { Simil } \\
\text { arity }\end{array}$ & $\begin{array}{l}\text { Trustwo } \\
\text { rthiness }\end{array}$ \\
\hline Expertise & 0.91 & & & & & \\
\hline $\begin{array}{l}\text { Physical } \\
\text { Attractiven } \\
\text { ess }\end{array}$ & 0.221 & 0.848 & & & & \\
\hline
\end{tabular}




\begin{tabular}{|l|l|l|l|l|l|l|}
\hline $\begin{array}{l}\text { Purchase } \\
\text { Intentions }\end{array}$ & 0.119 & 0.564 & ${ }^{* * *} 0.861$ & & & \\
\hline Respect & 0.190 & 0.401 & 0.539 & $\begin{array}{r}* * * \\
038\end{array}$ & & \\
\hline Similarity & 0.125 & 0.435 & 0.554 & 0.56 & 0.8 & \\
\hline $\begin{array}{l}\text { Trustworth } \\
\text { iness }\end{array}$ & 0.164 & 0.458 & 0.460 & 0.49 & 0.311 & 0.837 \\
\hline
\end{tabular}

Notes: ${ }^{* * * *}$ Square Root AVE

According to Hair et al. (2013), outer loading indicators should be higher than 0.708 . Indicators with outer loading values between 0.40 and 0.70 should be considered for removal. All the indicators were higher than 0.708 except for indicator A4, at 0.656. After removing this item, the outer model was re-evaluated and Table II shows the composite reliability, indicator reliability and convergent validity of the remaining reflective constructs. The composite reliability value of all six latent variables was higher than 0.708 , so these variables can all be considered acceptable for testing the model. For convergent validity, the average variance extracted (AVE) should be higher than 0.50. In fact, the AVE values ranged from 0.701 to 0.831 . This indicates that, on average, these constructs explain more than half of the variance of their indicators and that there is therefore a good fit between the constructs and their underlying indicators.

Table III shows the results of the discriminant validity test, based on cross-loading values, which is the correlation between the variables and the Square root AVE values. Using the Fornell-Larcker criterion, discriminant validity tests were conducted on each pair of correlations by comparing the square root AVE of each construct and the correlations between the constructs. As suggested by Hair et al. (2013), the square root of the AVE of each construct should be higher than its highest correlation with any other constructs; moreover, every indicator's outer loadings on the constructs should be higher than all its cross-loadings with other constructs. All the constructs emerged as valid and reliable. As such, the selected measurements are valid and reliable enough for further testing. 


\begin{tabular}{|c|c|}
\hline Hypotheses Relationships & Values \\
\hline & $\mathbf{R}^{\mathbf{2}}=\mathbf{0 . 4 9 1}$ \\
\hline $\mathrm{T}$ - P (H1) & $\beta=0.142, \mathrm{t}=2.695^{*}$ \\
\hline $\mathrm{E}$ - P (H2) & $\beta=-0.045, \mathrm{t}=1.073$ \\
\hline A - P (H3) & $\beta=0.312, \mathrm{t}=6.054^{*}$ \\
\hline $\mathrm{R}-\mathrm{P}(\mathrm{H} 4)$ & $\beta=0.200, \mathrm{t}=4.183^{*}$ \\
\hline $\mathrm{S}-\mathrm{P}(\mathrm{H} 5)$ & $\beta=0.266, \mathrm{t}=4.912^{*}$ \\
\hline
\end{tabular}

Notes: *p <0.05; T-Trustworthiness; E-Expertise; A-Physical Attractiveness; $R=$ Respect; S-Similarity; P-Purchase intentions

Out of the five hypotheses as indicated in Table IV, four were found to be significant and supported, while H2 was not supported. Six indicators were used to measure trustworthiness. The overall empirical results show that the trustworthiness of celebrity endorsers has a positive and significant relationship with consumers' purchase intentions $(\beta=0.142, \mathrm{t}=$ 2.695). Overall, the indicators of the attribute "trustworthiness" did not receive high scores. This suggests that the respondents place more emphasis on other attributes of celebrity endorsers rather than on trustworthiness. The conclusion to be drawn is that while trustworthiness may be the least important determinant in predicting Malaysian young adults' purchase intentions when faced with celebrity endorsers, respondents still do attach some importance to the trustworthiness of celebrities. These findings are consistent with those of Priester \& Petty (2003) and Erdogan (1999), who concluded that if a celebrity endorser were perceived to be highly trustworthy, consumers would be more likely to accept unthinkingly their advertising message as valid instead of scrutinizing and analyzing it.

The impact of the expertise of celebrity endorsers on purchasing intentions was evaluated using six indicators. The results $(\beta=-0.045, \mathrm{t}=1.073)$ show that the expertise of celebrity endorsers is not statistically significant and does not significantly affect consumers' purchase intentions. The t-statistics show that the expertise of celebrity endorsers received the lowest score of all the indicators, suggesting that this factor was the least influential on consumers' purchase intentions. These findings contradict most prior literature. Most research present expertise as an important factor in increasing the persuasiveness of advertising messages and contends that the expertise of a celebrity endorser can lead to a positive attitude change and thereby generate purchase intentions. In fact, Evans (1988) found that celebrities who endorse 
products and services perceived as far from their own fields of expertise can indirectly hurt consumers' perceived images, resulting in negative purchase intentions. Presumably this is because respondents do not think the endorsers are experts on the products they are endorsing, or, by extension, have a good understanding of, or, are knowledgeable about the product in question. Nevertheless, this study has found that expertise is not a critical factor in influencing Malaysian consumers' purchase intentions. It can be concluded that young adults consider other factors of celebrity endorsers as more important compared to their expertise.

The results show that the physical attractiveness of celebrity endorsers has a positive and statistically significant relationship with consumers' purchase intentions $(\beta=0.312, \mathrm{t}=$ 6.054). Indeed, they suggest that physical attractiveness is the most important determinant in predicting consumers' purchase intentions. The physical attractiveness of celebrity endorsers was evaluated via five indicators and based on the t-values, A6 (91.15) emerged with the highest score, which implies that the attractiveness of endorsers has the most influential effect on consumers' purchase intentions. This is followed closely by A2 (88.30), i.e. charisma; then some way behind by A1 - beautiful (44.45) and then A5 - good looking (26.22). Many studies have shown that people respond favorably to endorsements if the endorsers are attractive and desirable (Bryne, Whitehead \& Breen, 2003). In fact, Liu et al. (2007) found that consumers usually require endorsers to be physically attractive if they are to increase the recognition of and purchase intentions towards a product or service. In sum, the physical attractiveness of endorsers undoubtedly has a significant effect on consumers and is a very important factor for Malaysian consumers.

The respect for celebrity endorsers was evaluated using six indicators The overall empirical results show that respect for celebrity endorsers has a positive and significant relationship with consumers' purchase intentions $(\beta=0.200, t=4.183)$. In fact, respect emerged the second most important determinant in predicting consumers' purchase intentions in this study. Statement R5 ( $\mathrm{t}=80.09)$ had the highest $\mathrm{t}$-statistical value, and R3 (70.88) the second highest, indicating that having an appealing personality and being admired are the most influential characteristics of celebrity endorsers. These are followed by the endorsers' acting or singing ability or athletic prowess $(\mathrm{R} 4, \mathrm{t}=50.70)$. This outcome is similar to the findings of Atkin and Block (1983). Their studies found that celebrity endorsers are beneficial to advertising messages and are most effective in influencing consumers' attitudes when the 
celebrities are respected. Further, Shimp (2003) suggested that if a celebrity endorser is respected, the respect for the celebrity might extend to the brand, and this could lead to a positive attitude towards the brand. In all, if celebrities are respected/well-liked, consumers are far more likely to purchase the products or services endorsed by them.

The results further show that the similarity of celebrity endorsers has a positive and significant relationship with consumers' purchase intentions $(\beta=0.266, \mathrm{t}=4.912)$. The bootstrapping procedure produced the highest score for S5 (68.75), indicating that respondents felt they had a lot in common with endorsers and that this indicator has the most influential impact on consumers' purchase intentions. This was followed by S6 (56.54) and S1 (52.92) respectively - indicating that consumers who feel they share similar opinions with celebrity endorsers and identify with the endorser can have a significant effect on their purchase intentions. Overall, similarity emerged as the third most important factor and this is consistent with earlier studies. In sum, if consumers perceive themselves to have a greater similarity with a celebrity or feel they have something in common with him or her, then they are more likely to purchase the product in question.

\section{Purchase Intentions}

Overall, the findings of this study support the contention that celebrity endorsers produce more positive attitudes and greater purchase intentions. More specifically, over half of the respondents $(56 \%)$ surveyed in this study said they were likely to purchase a product endorsed by a celebrity; $61 \%$ were likely to try a product endorsed by celebrity if they saw it in a store; $55.3 \%$ were likely to actively seek out a product endorsed by a celebrity in a store; and $54.7 \%$ were overall happy to purchase products or services advertised by celebrities. In fact, $\mathrm{Xu}$ (2008) found that celebrity endorsers can help boost the effectiveness of advertising, and are most effective in influencing the attitudes of consumers because they are respected by and are highly identifiable with young adults. It would seem that young adults are more readily persuaded when a celebrity is linked to a product, possibly because they are at still at an impressionable stage of development. In sum, endorsement by a celebrity can have a meaningful and impactful influence on many young adults' evaluation of advertisements and products. 
To further understand consumers' purchase intentions, this question was posed: "How likely are you to buy a product if there is 'negative publicity' about the endorser?" A fairly large number of respondents, $41.8 \%$ were neutral about the impact of negative publicity on their purchase intentions. While this reply is not as strong as an outright negative or positive response, the hesitance of respondents to indicate positive purchase intentions does suggest that they may possibly lean more towards not purchasing the product. Meanwhile, $32.4 \%$ of respondents said they were unlikely to purchase products if the celebrity is associated with negative publicity; while $25.8 \%$ said they would. Using the mean value (2.88) to derive a conclusion, it is clear that most respondents were unlikely to purchase a product endorsed by a celebrity facing negative publicity. This is clearly a risk for advertisers.

A test on purchase intentions by gender produced no significant difference. This result contradicts earlier literature and ELM studies. One possible explanation for the surprising results of this study is the age profile of the respondents in this research: young adults between 18-25 years, who are more exposed to the media, and more aware of and familiar with many celebrities. Therefore, both males and females could be similarly influenced by celebrities and have notably more favorable attitudes towards products endorsed by them.

The tests in this study for race, in contrast, showed significant differences in purchase intentions as a result of celebrity endorsement. The Chinese were the most likely to purchase a product endorsed by celebrities, followed by the Indians and Malays. This is consistent with a study by Rashid, Nallamuthu \& Sidin (2002), which suggested that there are significant differences between Malay, Chinese and Indian consumers' attitudes towards advertising by celebrities, with the Chinese being most familiar with certain celebrities. As such, race is an influential factor with regard to celebrity endorsement. This may be due to cultural differences among the three races particularly their beliefs and religious traditions. This study also suggests that Chinese consumers' attitudes towards celebrity endorsement experience more changes through the peripheral route than those of Indian and Malay consumers.

\section{Conclusion}

This study found that the physical attractiveness of a celebrity has the highest impact on consumers' purchase intentions, followed by respect and similarity. The least influential attribute is trustworthiness. However, advertisers need to bear in mind that celebrity 
endorsers cannot be selected on the basis of one attribute only; they also need to consider the other influential attributes of celebrities, as these attributes can collectively strengthen the positive impact of a celebrity on consumers' purchase intentions. Interestingly, the expertise of a celebrity endorser is not an important factor in influencing Malaysian young adults' purchase intentions. Another significant finding is that over half of the respondents were likely to purchase products endorsed by celebrities if they saw it in a store - reflecting perhaps the fact that the young adults are more familiar with and influenced by celebrities. And finally, Chinese consumers' attitudes tend to change via the peripheral route more than those of the other races, indicating that they are more susceptible to the influence of celebrity endorsements compared to the Malays and Indians.

The outcome of this study is particularly valuable with regard to the relationship between the specific attributes of endorsers contained in the TEARS model and consumers' purchasing intentions. It also supports the validity of the persuasion process in the ELM theoretical framework. 


\section{References}

Atkin, C. \& Block, M. (1983) Effectiveness of celebrity endorsers. Journal of Advertising Research. 23 (1). p.57-61.

Benoit, L., Stephenson, T. \& Tschida, A. (2001) Communication Studies. 52 (4).

Belch, G. \& Belch, M. (2003) Advertising and Promotion: An Integrated Marketing Communication Perspective. 6th Ed. London: Irwin/McGraw-Hill.

Biswas, D., Biswas, A. \& Das, N. (2006) The differential effects of celebrity and expert endorsements on consumer risk perceptions. Journal of Advertising. 35. p.17-31.

Biswas, S., Hussain, M., \& O’Donnell, K. (2009) Celebrity endorsements in advertisements and consumer perceptions: A cross-cultural study. Journal of Global Marketing. 22. p.121-137.

Brown M. (2011) Do men and women respond differently to ads? [Online] Available from: http://www.wpp.com/NR/ rdonlyres /1DD86CF1-C93A-49C6-94FC 653889D60652/0/millward_brown_men_women.pdf.

Bryne, A., Whitehead, M. \& Breen, S. (2003) The Naked Truth of Celebrity Endorsement. British Food Journal 105 (4). 288-296.

Carroll, A. (2008) Brand Communications Fashion Categories using Celebrity Endorsement. Brand Management.17(2).146-158.

Charbonneau, J. \& Garland, R. (2005) Talent, looks or brains? Marketing Bulletin. 16. p. 110.

Chen, S.M. \& Huddleston, P. (2009) A Comparison of Four Strategies to Promote Fair Trade Products. International Journal of Retail and Distribution Management. 37 (4). p. 336-345.

Choi, S.M. \& Rifon, N. (2007) Who Is the Celebrity in Advertising? Understanding the Dimensions of Celebrity Images. Journal of Popular Culture. 40 (2). p. 304-324.

Cialdini, R. B. (2007). Influence: The psychology of persuasion. New York: Harper Collins.

Daneshvary, R., \& Shwer, K. (2000) The accocaition endorsement and consumers' intention to purchase. Journal of Consumer Makering. 17 (3). p. 203-213.

Desphande, R., \& Stayman, D. (1994) A tale of two cities: Distinctness theory and advertising effectiveness. Journal of Marketing Research. 3 (1). p. 57-64. 
Department of Statistics Malaysia (2013) Population and Demography. [Online] Available from: http://www.statistics. gov.my/ portal/download_Population/files/demo/Risalah_Indikator_Demografi_Malaysia_201 3.pdf.

Elliott, R. (2006) Strategic Brand Management. Oxford: Oxford University Press.

Erdogan, B. Z. (1999). Celebrity Endorsement: A Literature Review. Journal of Marketing Management. 15. p. 291-314.

Ericsson, L. \& Hakansson, E. (2005) Athletes as celebrity endorsers - Case studies from Sweden. [Online] Available from: https://pure.ltu.se/ws/files/30952031/LTU-SHUEX05049-SE.pdf\%202005.

Evans, R. B. (1988) Producing and creativity in advertising. London: Pitman Publishing.

Farhat, R., \& Khan, B.M. (2011) An Exploratory Study of Celebrity Endorsements. p. 463466. Singapore: IACSIT Press.

Forbes (2011) Hollywood's Most Trustworthy Celebrities. [Online] Available from: http://www.forbes.com/2011/02/07/most-trustworthy-celebrities-businessentertainment.html.

Forbes (2014) The World's Most Powerful Celebrities, [Online] Available from: http://www.forbes.com/celebrities/.

Friedman H. \& Friedman L. (1979) Endorsers effectiveness by Product Type. Journal of Advertising Research. 19. 63-71.

Hoyer, W. \& MacInnis, D. (2007) Consumer Behavior. Boston: Houghton Mifflin.

Hair, F., Hult G., Ringle M., \& Sarstedt (2013) A Primer on Partial Least Squares Structural Equation Modeling (PLS-SEM). Sage Publications.

Johansson, J. \& Sparredal, J. (2002) Celebrity endorsements: A case study of Axa and the Ludmila Engquist incident. [Online] Available from: http://epubl.luth.se/1404 5508/2002/112/LTU-SHU-EX-02112-SE.pdf.

Kambitssis, C., Harahousou, Y., Theodorakis, N., \& Chatzibeis, G. (2002) Sports Advertising in Print Media: The case of 2000 Olympic Games. Corporate Communications: An International Journal. 7 (3). p. 155-161.

Kahle, L.R. \& Homer, P. (1985) Physical attractiveness of the celebrity endorser: a social adaptation perspective. Journal of Consumer Research. 11 (3). p. 954-61. 
Kwek C. L. (2010) The Effects of Shopping Orientations, Online Trust and Prior Online Purchase Experience toward Customers' Online Purchase Intention. International Business Research. 3 (3).

La Eerie, C. \& Sejung, M. C. (2005) The association of perceived endorser credibility in South Korean advertising Journal of current issues \& research advertising. 21 (2). p. 67-81.

Liu, M. T., Huang, Y., \& Jiang, M. H. (2007) Relations among attractiveness of endorsers, match- up and purchase intention in sport marketing in China. Journal of Consumer Marketing. 24 (6). p. 358-365.

Magnini, P.V., Honeycutt, E. D., \& Cross, A. M. (2008) Understanding the use of celebrity endorsers for hospitality firms. Journal of Vacation Marketing 14 (1). p. 57-69.

McCracken, G. (1989) Who is the Celebrity Endorser? Cultural Foundation of the Endorsement Process. Journal of Consumer Research. 16. p. 310-321.

Mehta, A. (1994) How Advertising Response Modelling (ARM) Can Increase Ad Effectiveness. Journal of Advertising Research. 34 (3). p. 62-74.

Mustafa, N. (2005) The Role of Celebrities in Marketing. A background paper for class Creatives: Stars in our eyes. London: City University.

Nelson, O. (2010) Celebrity advertising and its effectiveness on brand loyalty interdisciplinary. Journal of Contemporary Research in Business. 1 (9). p. 70-85.

Ohanian R. (1990) Construction and Validation of a Scale to Measure Celebrity Endorsers' Perceived Expertise, Trustworthiness and Attractiveness. Journal of Advertising Research. 19 (3). p. 39-52.

Ohanian, R. (1991) The impact of celebrity spokespersons' perceived image on consumers' intention to purchase. Journal of Advertising Research. 31 (3). p. 46-52.

O'Mahony, S. \& Meenaghan, T. (1997) The impact of celebrity endorsements. Irish Marketing Review. 10(2). 15-24.

Petty, R. E., Cacioppo, J. T. \& Schuman, D. (1983) Central and Peripheral Routes to Advertising Effectiveness: The Moderating Role of Involvement. Journal of Consumer Research. 10 (2). p.135-146.

Pornpitakpan, C. (2003) The Effect of Celebrity Endorsers' Perceived Credibility on Product Purchase Intention: The Case of Singaporeans. Journal of International Consumer Marketing. 16 (2). p. 55-74. 
Pringle, H. \& Binet, L. (2005) How marketers can use celebrities to sell more effectively, Journal of Consumer Behavior. 4 (3). 201-214.

Priester, J. R., \& Petty, R. E. (2003) The influence of spokesperson trustworthiness on message elaboration, attitude strength, and advertising effectiveness. Journal of Consumer Psychology. 13 (4). p. 408-421.

Rashid, A., Nallamuthu, J. \& Sidin, S. (2002) Perceptions of Advertising and Celebrity Endorsement in Malaysia. Asia Pacific Management. 7 (4). p. 535-554.

Roll, M. (2006) Asian brand strategy: How Asia builds strong brands. Palgrave Macmillan, Hampshire, New York.

Roy, S. (2006) An Exploratory Study in Celebrity Endorsements. Journal of Creative Communications 1(2). Sage Pub.

Spears, N. \& Singh, S. N. (2004) Measuring Attitude toward the Brand and Purchase Intentions. Journal of Current Issues and Research in Advertising. 26 (2). p. 53-66.

Song, G. F., Chaipoopiratana, S., Combs, H., (2008) A study of Chinese advertising practitioner's perspectives on the selection of celebrity endorsers. Journal of Business and Behavioral Sciences. 19 (1). p. 17-32.

Sheu, J. B. (2010) A hybrid dynamic forecast model for analyzing celebrity endorsement effects on consumer attitudes. Mathematical and Computer Modeling. 52 (9). p. 1554-156.

Silvera, D.H. \& Austad, B. (2004) Factors predicting the effectiveness of celebrity endorsement advertisements. European Journal of Marketing, 38 (11/12). p.15091526.

Shimp, T. A. (2003) Advertising, Promotion and Supplemental Aspects of Integrated Marketing Communications. 6th Ed. Thomson South Western.

Shimp T. A. \& Andrews J. (2013) Advertising, Promotion, and other aspects of Integrated Marketing Communications. 9th Ed. South-Wester Cengage learning.

Temperley, J.\& Tangen, D. (2006) The Pinocchio factor In Consumer Attitudes Towards Celebrity Endorsement: Celebrity Endorsement, The Reebok Brand, And An Examination Of A Recent Campaign. Innovative Marketing. 2(3). Special Edition on Consumer Satisfaction - Global Perspective.

Tan, K. (2011) Riding on the star power. The Edge Malaysia. [Online Available from: http://www. theedgemalaysia.com] 
Till, B. \& Busler, M. (2000) The Match-Up Hypothesis: Physical Attractiveness, Expertise, and the Role of Fit on Brand Attitude, Purchase Intent and Brand Beliefs. Journal of Advertising. 29 (3). p. 1-13.

Tom, G., Clark, R., Elmer, L., Grech, E., Masetti J.\& Sandhar, H. (1992) The Use of Created versus Celebrity Spokesperson in Advertisement. The Journal of Consumer Research. 20 (4). p. 535-547.

Toncar, M., Reid, J. S. \& Anderson, C. E. (2007) Effective spokespersons in a public service announcement: national celebrities, local celebrities, and victims. Journal of Communication Management. 11 (3). p. 258-275.

Wang, W. C. (2006) The effect of product knowledge and brand image on purchase intention moderated by product category. Thesis for the Master of Philosophy. Taiwan: Tatung University.

Wagner, B. C., \& Petty, R. E. (2011) The elaboration likelihood model of persuasion: Thoughtful and non-thoughtful social influence. Theories in social psychology. p. 96116.

White, D.W., Goddard, L. \& Wilbur, N. (2009) The effects of negative information transference in the celebrity endorsement relationship. International Journal of Retail \& Distribution Management. 37 (4). p. 322-335.

$\mathrm{Xu}, \mathrm{Y}$. J. (2008) The influence of public self-consciousness and materialism on young consumer's compulsive buying. Young Consumers: Insight and Ideas for Responsible Marketers. 9 (1). p. 37-48. 